\title{
Molecular characterization of the Great Lakes viral hemorrhagic septicemia virus (VHSV) isolate from USA Arun Ammayappan ${ }^{1,2}$ and Vikram N Vakharia*1
}

Address: ${ }^{1}$ Center of Marine Biotechnology, University of Maryland Biotechnology Institute, Baltimore, 701 East Pratt Street, Baltimore, Maryland 21202-3101, USA and 2Department of Veterinary Medicine, University of Maryland, College Park, MD 20742, USA

Email: Arun Ammayappan - ammayapp@umbi.umd.edu; Vikram N Vakharia* - vakharia@umbi.umd.edu

* Corresponding author

Published: 25 October 2009

Virology Journal 2009, 6:17I doi:I0.1186/|743-422X-6-17|

This article is available from: http://www.virologyj.com/content/6/I/I7I

This is an Open Access article distributed under the terms of the Creative Commons Attribution License (http://creativecommons.org/licenses/by/2.0), which permits unrestricted use, distribution, and reproduction in any medium, provided the original work is properly cited.

\begin{abstract}
Background: Viral hemorrhagic septicemia virus (VHSV) is a highly contagious viral disease of fresh and saltwater fish worldwide. VHSV caused several large scale fish kills in the Great Lakes area and has been found in 28 different host species. The emergence of VHS in the Great Lakes began with the isolation of VHSV from a diseased muskellunge (Esox masquinongy) caught from Lake St. Clair in 2003. VHSV is a member of the genus Novirhabdovirus, within the family Rhabdoviridae. It has a linear single-stranded, negative-sense RNA genome of approximately I I kbp, with six genes. VHSV replicates in the cytoplasm and produces six monocistronic mRNAs. The gene order of VHSV is 3'-N-P-M-G-NV-L-5'. This study describes molecular characterization of the Great Lakes VHSV strain (MIO3GL), and its phylogenetic relationships with selected European and North American isolates.

Results: The complete genomic sequences of VHSV-MI03GL strain was determined from cloned cDNA of six overlapping fragments, obtained by RT-PCR amplification of genomic RNA. The complete genome sequence of MI03GL comprises II, I84 nucleotides (GenBank GQ38594I) with the gene order of 3'-N-P-M-G-NV-L-5'. These genes are separated by conserved gene junctions, with di-nucleotide gene spacers. The first 4 nucleotides at the termini of the VHSV genome are complementary and identical to other novirhadoviruses genomic termini. Sequence homology and phylogenetic analysis show that the Great Lakes virus is closely related to the Japanese strains JFO0Ehil (96\%) and KRRV9822 (95\%). Among other novirhabdoviruses, VHSV shares highest sequence homology (62\%) with snakehead rhabdovirus.

Conclusion: Phylogenetic tree obtained by comparing 48 glycoprotein gene sequences of different VHSV strains demonstrate that the Great Lakes VHSV is closely related to the North American and Japanese genotype IVa, but forms a distinct genotype IVb, which is clearly different from the three European genotypes. Molecular characterization of the Great Lakes isolate will be helpful in studying the pathogenesis of VHSV using a reverse genetics approach and developing efficient control strategies.
\end{abstract}




\section{Background}

Viral hemorrhagic septicemia virus (VHSV) is a rhabdoviral fish pathogen, which constitute one of the major threats to the development of the aquaculture industry worldwide. VHSV causes disease not only in salmonids, but also in many other marine species as well [1-5]. The virus usually causes severe hemorrhages on the skin, the kidney and the liver, with mortality rates as high as $90 \%$. VHSV is a member of the genus Novirhabdovirus within the family Rhabdoviridae [6]. It possess a non-segmented negative-strand RNA genome of approximately $11 \mathrm{kbp}$ with a coding capacity for five structural proteins; nucleoprotein $(\mathrm{N})$, phosphoprotein $(\mathrm{P})$, matrix protein $(\mathrm{M})$, glycoprotein $(\mathrm{G})$, RNA polymerase (L), and a nonstructural protein (NV) [7-9]. The gene order of VHSV is 3'-leader-N-P-M-GNV-L-trailer-5'. The negative-strand RNA genome is connected tightly with the nucleoprotein $\mathrm{N}$ and forms the core structure of virion. This encapsidated genomic RNA is also associated with the phosphoprotein $\mathrm{P}$ and polymerase protein $\mathrm{L}$, which are involved in viral protein synthesis and replication.

The complete nucleotide sequence of VHSV has been determined initially for VHSV Fi13 strain [9] and coding regions of several other strains of VHSV have been determined later [10]. In this study, we characterized the entire genome of the Great Lakes VHSV isolate MI03GL from muskellunge, Esox masquinongy (Mitchill), caught from the NW region of Lake St. Clair, Michigan, USA in 2003 [11]. Affected fish exhibited congestion of internal organs; the inner wall of the swim bladder was thickened and contained numerous budding, fluid-filled vesicles. Lake St. Clair is a major lake in the Great Lakes system that has historically supported an economically and socially important sport fishery for many species of fish [11,12]. VHSV has a very broad host-range, including numerous taxonomic families of fish. The Great Lakes VHSV has been found in 28 different host species, including muskellunge, yellow perch, smallmouth bass, northern pike, whitefish, walleye, bluegill, drum, round gobies, and some sucker species http://dnr.wi.gov/fish/vhs/. It is a serious threat to all aquaculture species, including salmonids such as trout and salmon. To understand the molecular characteristics of the Great Lakes VHSV strain MI03GL, we thoroughly analyzed the entire genomic sequences and compared it with other VHSV strains and rhabdoviruses.

\section{Methods}

\section{RT-PCR amplification of the VHSV genome}

The genomic RNA of VHSV strain MI03GL was kindly provided by Dr. Gael Kurath, U.S. Geological Survey, Western Fisheries Research Center, Seattle, WA, and was used as a template. The consensus PCR primers were designed based on the available VHSV genome sequences (Genbank accession numbers AB179621; NC 000855;
AB490792) from the National Center for Biotechnology Information (NCBI). The complete genome sequences were aligned; highly conserved sequence segments identified, and used to design overlapping primers. The oligonucleotide primers used in this study are listed in Table 1. First strand synthesis was carried out in a tube containing $5 \mu \mathrm{l}$ of RNA, which was denatured at $70^{\circ} \mathrm{C}$ for $10 \mathrm{~min}$ in the presence of DMSO $(3 \mu \mathrm{l}), 1 \mu \mathrm{l}$ forward gene-specific primer, $1 \mu \mathrm{l}$ of $25 \mathrm{mM}$ dNTPs, and snap-cooled on ice for $1 \mathrm{~min}$. The reaction mixture containing $2 \mu \mathrm{l}$ of $10 \times \mathrm{RT}$ buffer, $2 \mu \mathrm{l}$ of $0.1 \mathrm{M}$ DTT, $4 \mu \mathrm{l}$ of $25 \mathrm{mM} \mathrm{MgCl}_{2}, 1 \mu \mathrm{l}$ of Superscript III RT ${ }^{\mathrm{TM}}$, and $1 \mu \mathrm{l}$ of RNase OUT ${ }^{\mathrm{TM}}$ was incubated at $50^{\circ} \mathrm{C}$ for $1 \mathrm{~h}$. PCR amplifications were carried out using a $p f x 50^{\mathrm{TM}}$ PCR kit (Invitrogen, CA), according to manufacturer's instructions. Briefly, the following mixture was used for PCR amplification: $3 \mu 1$ of cDNA, $2 \mu \mathrm{l}$ of primer mix; $5 \mu$ l of $10 \times$ PCR buffer [ $100 \mathrm{mM}$ Tris-HCl $(\mathrm{pH}$ 9.0), $500 \mathrm{mM} \mathrm{KC1,} \mathrm{1 \%} \mathrm{Triton} \mathrm{X-100],} 2 \mu 1$ of $25 \mathrm{mM}$ $\mathrm{MgCl}_{2}, 0.5 \mathrm{ul}$ of $p f x 50$ polymerase, and $37 \mu 1$ of DEPC water, to make a final volume of $50 \mu 1$. Reaction was carried out in a thermal cycler (MJ Research Inc., Waltham, $\mathrm{MA}$ ), using the following program: denaturation at $94^{\circ} \mathrm{C}$ for $30 \mathrm{sec}$; annealing for $30 \mathrm{sec}$ at $60^{\circ} \mathrm{C}$; and extension at $68^{\circ} \mathrm{C}$ for $2 \mathrm{~min}$. The RT-PCR products were separated by agarose gel electrophoresis and purified using a QIAquick gel extraction kit (Qiagen, CA).

In order to identify the 3 '-terminal region of the genomic RNA, poly (A) tail was added to the 3'-end with poly (A) polymerase enzyme, according to manufactures' instruction (Applied Biosystems, USA). Tailing reaction was carried in a tube containing $30 \mu \mathrm{l}$ of RNA, $26 \mu \mathrm{l}$ of nucleasefree water, $20 \mu \mathrm{l}$ of $5 \times$ poly (A) polymerase buffer, $10 \mu \mathrm{l}$ of $25 \mathrm{mM} \mathrm{MnCl}_{2}, 10 \mu \mathrm{l}$ of $10 \mathrm{mM} \mathrm{ATP}$, and $4 \mu \mathrm{l}$ of E. coli poly (A) polymerase. The reaction mixture was incubated at $37^{\circ} \mathrm{C}$ for $1 \mathrm{hr}$ and then RNA was purified using a Qiagen RNAeasy kit, according to manufacturer's instructions. The cDNA synthesis and polymerase chain reaction were conducted as described above, using an oligo (dT) primer (5'-GCGGCCGCTTTTTTTTTTTTTTTTTTTTT-3') for the first-strand synthesis, followed by PCR with the VHSVspecific primer 850R (5'-ACAGTCCAATCATGGTCATTC$3 '$ ). The 5'-terminal of genomic RNA was identified by rapid amplification of the 5'-end, using a 5'RACE kit (Invitrogen, USA), according to manufacturer's instructions.

\section{Cloning and sequencing}

The purified RT-PCR products were cloned into a pCR2.1 TOPO $^{\circledR}$ TA vector (Invitrogen, CA). Plasmid DNA from various clones was sequenced by dideoxy chain termination method, using an automated DNA sequencer (Applied Biosystems, CA). Three independent clones were sequenced for each amplicon to exclude errors that can occur from RT and PCR reactions. 
Table I: Oligonucleotides used for cloning and sequencing of the VHSV genome

\begin{tabular}{|c|c|c|}
\hline VHSV primers & Sequences & Position \\
\hline VHSV IF & GTATCATAAAATATGATGAGT & $|-2|$ \\
\hline VHSV IR & CAACTTGAACTTCTTCATGGC & $2028-2008$ \\
\hline VHSV $2 F$ & AAGAAGACCGACAACATACTCT & $1858-1879$ \\
\hline VHSV $2 R$ & GACGAAACTTTGAGAGGAGAAA & $3993-3972$ \\
\hline VHSV $3 F$ & АTCTCATTACCAACATGGCTCAAA & $3892-3915$ \\
\hline VHSV $3 R$ & TTGTTCGCTTCTCCCCTAATTGT & $5932-5910$ \\
\hline VHSV $4 \mathrm{~F}$ & TGCCATAGACCTACTCAAGTTAT & $58 \mid 4-5835$ \\
\hline VHSV 4R & CTGATCCATGGTGGCTATGTGAT & $8042-8020$ \\
\hline VHSV $5 \mathrm{~F}$ & AGATGATTGTCTCCACCATGAA & $7846-7867$ \\
\hline VHSV 5R & GAGATCCGCTCTCGTTCATCAA & $10027-10006$ \\
\hline VHSV $6 \mathrm{~F}$ & GACAAGAAAGCTGGGAAGAGA & $9787-9807$ \\
\hline VHSV 6R & GTATAGAAAATAATACATACCA & $11183-11162$ \\
\hline VHSV $850 R$ & ACAGTCCAATCATGGTCATTC & $85|-83|$ \\
\hline VHSV IMF & GGACAAAATGATCAAGTACATC & $595-616$ \\
\hline VHSV $2 M F$ & ССАTTСTСTGTGAAGATCAACAT & $2456-2478$ \\
\hline VHSV 3MF & TGTGAGACAGAAAGATGACGAT & $4566-4587$ \\
\hline VHSV 4MF & GACACCACCGAGAAGAGACTAC & $6429-6450$ \\
\hline VHSV 5MF & GAAGAGAAGGAAGCACACCAA & $8424-8444$ \\
\hline VHSV 5'EndI & GTGGCATCCGTCTTTCTCAA & $10599-10618$ \\
\hline VHSV 5'End2 & CGCTCATCACTCTCСTCGAA & $10660-10679$ \\
\hline Oligo (dT) & GCGGCCGCTTTTTTTTTTTTTTTTTTTTTTTT & \\
\hline
\end{tabular}

\section{Sequence and phylogenetic tree analysis}

The assembly of contiguous sequences and multiple sequence alignments were performed with the GeneDoc software [13]. The pair-wise nucleotide identity and comparative sequence analyses were conducted using Vector NTI Advance 10 software (Invitrogen, CA) and BLAST search from NCBI. Phylogenetic analyses were conducted using the MEGA4 software [14]. Construction of a phylogenetic tree was performed using the ClustalW multiple alignment algorithm and Neighbor-Joining method with 1000 bootstrap replicates.

\section{Database accession numbers}

The complete genome sequence of the VHSV MI03GL strain was submitted to the GenBank (accession number GQ385941). The accession numbers of other viral sequences used for sequence comparison and phylogenetic analysis are listed in Table 2.

\section{Results}

Complete nucleotide sequence of the VHSV strain MI03GL The entire genome of VHSV-MI03GL strain was amplified as six overlapping cDNA fragments that were cloned, and 
Table 2: Information about the viral hemorrhagic septicemia virus (VHSV) isolates used in this study for comparison and phylogenetic analysis

\begin{tabular}{|c|c|c|c|c|}
\hline S. No & Strain & Country & Host & GenBank no. \\
\hline \multicolumn{5}{|c|}{$\mathbf{N}$ protein } \\
\hline I. & $07-71$ & France & VHSV-infected cell line EPC & D00687 \\
\hline 2. & Makah & USA & Coho salmon & $\times 59241$ \\
\hline \multicolumn{5}{|c|}{ P protein } \\
\hline 3. & $07-7 \mid$ & France & rainbow trout & $\underline{\cup 02624}$ \\
\hline 4. & Makah & USA & Coho salmon & $\underline{\cup 02630}$ \\
\hline \multicolumn{5}{|c|}{ M protein } \\
\hline 5. & Makah & USA & Coho salmon & $\underline{\cup 03503}$ \\
\hline 6. & 07-7I & France & rainbow trout & $\underline{\cup 03502}$ \\
\hline \multicolumn{5}{|c|}{ G protein } \\
\hline 7. & NO-2007-50-385 & Denmark & rainbow trout & EU547740 \\
\hline 8. & Dwb97-04 & Germany & rainbow trout & EU708816 \\
\hline 9. & Datt 107 & Germany & rainbow trout & EU708734 \\
\hline 10. & Au9।7-04 & Austria & rainbow trout & EU708733 \\
\hline II. & Au28-95 & Austria & rainbow trout & EU708729 \\
\hline 12. & JF00Ehil & Japan & Japanese flounder & $\underline{A B 490792}$ \\
\hline 13. & BC99-00I & Canada & Pacific sardine & $\mathrm{DQ} 401195$ \\
\hline 14. & BC99-010 & Canada & Pacific herring & DQ40I194 \\
\hline 15. & ME03 & Canada & Atlantic herring & $\underline{\mathrm{DQ} 401192}$ \\
\hline 16. & JP99Obama25 & Japan & Japanese flounder & $\underline{D Q 401191}$ \\
\hline 17. & JP96KRRV960I & Japan & Japanese flounder & $\mathrm{DQ} 401190$ \\
\hline 18. & WA9IClearwater & USA & coho salmon & DQ401189 \\
\hline 19. & BC99-292 & Canada & Atlantic salmon & DQ401188 \\
\hline 20. & BC93-372 & Canada & Pacific herring & DQ401186 \\
\hline 21. & BC98-250 & Canada & Atlantic salmon & DQ401187 \\
\hline 22. & KRRV9822 & Japan & Japanese flounder & $\underline{A B \mid 79621}$ \\
\hline 23. & UK-MLA98/6PTI I & North Sea & Norway pout & AY546632 \\
\hline
\end{tabular}


Table 2: Information about the viral hemorrhagic septicemia virus (VHSV) isolates used in this study for comparison and phylogenetic analysis (Continued)

\begin{tabular}{|c|c|c|c|c|}
\hline 24. & UK-MLA98/6HEI & North Sea & herring & AY546631 \\
\hline 25. & UK-HI7/5/93 & North Sea, E. Shetland & $\operatorname{cod}$ & AY546630 \\
\hline 26. & UK-HI7/2/95 & North Sea, E. Shetland & haddock & AY546629 \\
\hline 27. & UK-860/94 & Gigha, W Scotland & turbot & AY546628 \\
\hline 28. & SE-SVA32 & Kattegat & Bottom-living* & AY546627 \\
\hline 29. & SE-SVA3I & Kattegat & herring & AY546626 \\
\hline 30. & NO-AI6368G & Norway & rainbow trout & AY546621 \\
\hline 31. & IR-FI3.02.97 & Ireland & turbot & AY546620 \\
\hline 32. & GE-I.2 & Georgia & rainbow trout & AY546619 \\
\hline 33. & FR-L59X & France & Eel & AY546618 \\
\hline 34. & FR-2375 & France & rainbow trout & AY546617 \\
\hline 35. & FI-ka422 & Gulf of Bothnia & rainbow trout & AY546615 \\
\hline 36. & DK-200079-I & Denmark & rainbow trout & $\underline{A Y 546613}$ \\
\hline 37. & DK-200098 & Denmark & rainbow trout & AY546605 \\
\hline 38. & DK-9895।74 & Denmark & rainbow trout & AY546603 \\
\hline 39. & DK-2835 & Denmark & rainbow trout & AY546585 \\
\hline 40. & DK-5I 23 & Denmark & rainbow trout & AY546588 \\
\hline $4 \mathrm{I}$. & DK-5e59 & Denmark & dab & AY546583 \\
\hline 42. & DK-Ip8 & Denmark & herring & AY546573 \\
\hline 43. & $\mathrm{CH}-\mathrm{Fl} 262 \mathrm{BFH}$ & Switzerland & rainbow trout & AY54657I \\
\hline 44. & AU-8/95 & Austria & rainbow trout & AY546570 \\
\hline 45. & DK-Ip52 & Denmark & sprat & AY546576 \\
\hline 46. & AYI67587 & Korea & olive flounder & AY 167587 \\
\hline 47. & Cod Ulcus & UK & Atlantic cod & $\underline{Z 93414}$ \\
\hline 48. & Hededam & Denmark & rainbow trout & $\underline{Z 93412}$ \\
\hline 49. & $96-43$ & UK & Atlantic herring & AFI43862 \\
\hline 50. & Fil3 & France & rainbow trout & Y18263 \\
\hline 51. & 02-84 France & France & Salmo trutta & $\underline{\mathrm{VHU}} 28800$ \\
\hline 52. & Makah & USA & Coho salmon & VHU28747 \\
\hline
\end{tabular}


Table 2: Information about the viral hemorrhagic septicemia virus (VHSV) isolates used in this study for comparison and phylogenetic analysis (Continued)

\begin{tabular}{|c|c|c|c|c|}
\hline 53. & FA28II07 & Norway & rainbow trout & EU481506 \\
\hline \multicolumn{5}{|c|}{ NV protein } \\
\hline 54. & DK-Ip55 & Baltic Sea & Sprat & DQ16280I \\
\hline 55. & DK-Ip53 & Baltic Sea & herring & DQ159195 \\
\hline 56. & DK-Ip52 & Baltic Sea & Sprat & DQ159194 \\
\hline 57. & DK-Ip49 & Baltic Sea & rockling & DQ159193 \\
\hline 58. & $\mathrm{FI}$ & Denmark & rainbow trout & $\underline{\cup 47848}$ \\
\hline 59. & $07-71$ & France & rainbow trout & $\underline{\cup 28746}$ \\
\hline 60. & Makah & USA & Coho salmon & $\underline{\mathrm{U} 28745}$ \\
\hline \multicolumn{5}{|c|}{ Complete genome } \\
\hline 61. & JF00Ehil & Japan & Japanese flounder & AB490792 \\
\hline 62. & FA28II 07 & Norway & rainbow trout & EU48I506 \\
\hline 63. & Fil3 & France & rainbow trout & $\underline{N C \quad 000855}$ \\
\hline 64. & KRRV9822 & Japan & Japanese flounder & $\underline{A B \mid 79621}$ \\
\hline 65. & Cod Ulcus & UK & Atlantic cod & $\underline{Z 934 I 4}$ \\
\hline 66. & Hededam & Denmark & rainbow trout & $\underline{Z 93412}$ \\
\hline 67. & $96-43$ & UK & Atlantic herring & $\underline{A F I 43862}$ \\
\hline 68. & $14-58$ & France & rainbow trout & $\underline{\mathrm{AFI}} 43863$ \\
\hline 69. & $07-7 \mid$ & France & rainbow trout & A) 233396 \\
\hline
\end{tabular}

Rhabdoviruses Complete Genome

\begin{tabular}{|c|c|c|}
\hline 70. & Rhabdovirus & GenBank no. \\
\hline 71. & Bovine ephemeral fever virus (BEFV) & NC_002526 \\
\hline 72. & European bat lyssavirus (Bat) & NC 009527 \\
\hline 73. & Northern cereal mosaic virus (Cereal) & NC_00225I \\
\hline 74. & Lettuce necrotic yellows virus (Lettuce) & NC 007642 \\
\hline 75. & Maize Fine streak virus & NC_005974 \\
\hline 76. & Maize mosaic virus (MMV) & NC 005975 \\
\hline 77. & Mokola virus & NC_006429 \\
\hline 78. & Orchid fleck virus (OFV) & NC 009609 \\
\hline
\end{tabular}


Table 2: Information about the viral hemorrhagic septicemia virus (VHSV) isolates used in this study for comparison and phylogenetic analysis (Continued)

\begin{tabular}{|c|c|c|}
\hline 79. & Rabies virus & NC_001542 \\
\hline 80. & Siniperca chuatsi rhabdovirus & NC 008514 \\
\hline 81. & Spring viremia of carp virus (SVC) & NC_002803 \\
\hline 82. & Sonchus yellow net virus (SYN) & $\underline{N C 001615}$ \\
\hline 83. & Taro vein chlorosis virus (Taro) & $\begin{array}{ll}\text { NC } & 006942 \\
\text { NC } & 006942 \\
\text { NC } & 006942 \\
\end{array}$ \\
\hline 84. & Tupaia rhabdovirus & NC 007020 \\
\hline 85. & Vesicular stomatitis virus (VSV) & NC_00I560 \\
\hline 86. & Infectious hematopoietic necrosis virus (IHNV) & $\underline{\times 89213}$ \\
\hline 87. & Hirame rhabdovirus (HIRRV) & NC_005093 \\
\hline 88. & Snakehead rhabdovirus (SHRV) & NC 000903 \\
\hline
\end{tabular}

*Virus was isolated from pool of Pholis gunellus, Gobiidae species, Zoarces viviparous and Acanthocottus scorpius.

the DNA sequenced (Fig. 1). The complete genome sequence of VHSV-MI03GL comprises 11,184 nucleotides (nts) and contains six genes that encode the nucleocapsid $(\mathrm{N})$ protein, the phosphoprotein $(\mathrm{P})$, the matrix protein $(\mathrm{M})$, the glycoprotein $(\mathrm{G})$, the non-virion $(\mathrm{NV})$ protein, and the large (L) protein (Fig. 1). The gene order is similar to other novirhabdoviruses, 3'-N-P-M-G-NV-L-5'. The genomic features and predicted proteins of the VHSV strain MI03GL are shown in Table 3. All the open reading frames (ORFs) are separated by untranslated sequences, known as gene junctions, whereas the untranslated regions at the 3'- and 5'- ends are known as the 'leader' and 'trailer', respectively. For example, the $\mathrm{N}$ gene is composed of 1,388 nts, and is located between 54 and 1441 nts from the 3'-end of the genomic RNA. The ORF of N gene is flanked by $113 \mathrm{nts}$ and $60 \mathrm{nts}$ of 5 '- and 3'-untranslated regions (UTRs), respectively, and encodes a protein of 404 amino acids, with a calculated molecular weight (MW) of $44.0 \mathrm{kDa}$. Similarly the length, ORF, and UTRs of the $\mathrm{P}, \mathrm{M}, \mathrm{G}, \mathrm{NV}$, and $\mathrm{L}$ genes, encoding respective proteins with their calculated MW, are depicted in Table 3.

\section{Genomic termini and untranslated sequences}

Rhabdoviruses have conserved untranslated regions between open reading frames for optimal translation of viral proteins [15]. These sequences consist of a putative transcription stop/polyadenylation motif (UCUAUCU ${ }^{7}$ ), which signals reiterative copying of the $U$ sequences to generate poly (A) tail to the mRNA. It is followed by an intergenic di-nucleotide $\mathrm{GC}$ or $\mathrm{AC}$, which is not tran- scribed, and a putative transcription start signal, -CGUG(Fig. 2A). All the genes contain these conserved gene end (GE), intergenic (IG) and gene start (GS) sequences, as shown in Fig. 2A.

Like other rhabdoviruses, the genomic termini of VHSV 3 '-terminal nucleotides exhibit complementarities to the nucleotides of the genomic 5'-terminus. Figure 2B shows that the first 4 nucleotides of 3 '-end are complementary to the 5 '-end nucleotides of genomic RNA, with the exception of an additional uracil (U) residue at the 5 '-terminal. The complementary nature of genomic termini allows a formation of a panhandle structure, which is important for replication of rhabdoviruses.

\section{Homology and phylogenetic analysis}

The percent nucleotide and deduced amino acid sequence identities of VHSV-MI03GL with known VHSV strains and other rhabdoviruses were determined by Vector NTI program and the results are shown in Tables 4 and 5, respectively. The complete genome comparison of MI03GL with other VHSV strains reveals a close relationship with two Japanese strains, which were isolated from Japanese flounder [JF00Ehi1 (96\%) and KRRV9822 (95\%)]. Other VHSV strains are only $86-87 \%$ identical to the MI03GL strain (Table 4). Similarly, the complete genome comparison of MI03GL strain with different members of Rhabdoviridae family shows $30-35 \%$ identity, but among novirhabdoviruses, it exhibits 56\% identity with infectious hematopoietic necrosis virus (IHNV) and 62\% with 


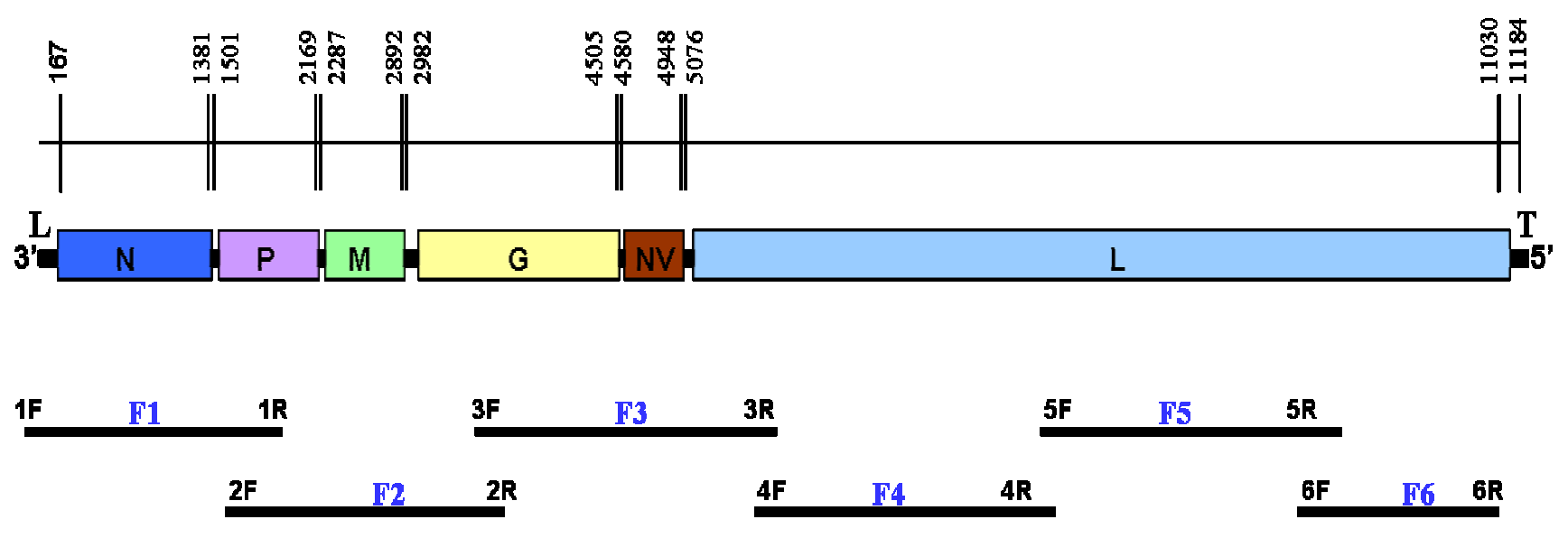

\section{Figure I}

Genetic map of the VHSV genome and cDNA clones used for sequence analysis. The location and relative size of the VHSV ORFs are shown; the numbers indicate the starts and ends of the respective ORFs. Six cDNA fragments (FI to F6) were synthesized from genomic RNA by RT-PCR. The primers used for RT-PCR fragments are shown at the end of each fragment. The RNA genome is II,I84 nucleotides long and contains a leader (L) and trailer (T) sequences at its 3'-end and 5'-end, respectively. The coding regions of $N, P, M, G, N V$ and $L$ genes are separated by intergenic sequences, which have gene-start and gene-end signals.

snakehead rhabdovirus (SHRV), as shown in Table 5. Also in novirhabdoviruses, it is evident that non-virion protein (which is absent in other rhabdoviruses) is highly variable than any other region of the genome, showing only 16$17 \%$ identity.

Figure 3 shows the phylogenetic trees generated by comparing the deduced amino acid sequences of VHSV strains and other rhabdoviruses belonging to Rhabdoviridae family. Phylogenetic tree obtained by comparing the deduced amino acid sequences of VHSVs shows that MI03GL strain is closely related to the Japanese strains, JF00Ehil and KRRV9822 (Fig. 3A), whereas phylogenetic tree obtained by comparing the deduced amino acid sequences of known rhabdoviruses reveals that viruses belonging to the same genera of Vesiculovirus, Lyssavirus, Ephemerovirus, Novirhabdovirus, Cytorhabdovirus, and Nucleorhabdovirus would form separate clusters (Fig. 3B).

Table 3: Genomic features and predicted proteins of the VHSV strain MI03GL

\begin{tabular}{|c|c|c|c|c|c|c|c|c|c|}
\hline S. No & Gene & Start & End & 5'UTR & ORF & 3'UTR & Total Length ${ }^{a}$ & Protein Size (aa) & MWb \\
\hline I. & Leader & 1 & 53 & & & & 53 & & \\
\hline 2. & $\mathrm{~N}$ & 54 & |44| & 113 & 1215 & 60 & 1388 & 404 & 44.0 \\
\hline 3. & $P$ & 1444 & 2203 & 57 & 669 & 34 & 760 & 222 & 24.4 \\
\hline 4. & $M$ & 2206 & 2946 & 81 & 606 & 54 & 741 & 201 & 22.3 \\
\hline 5. & G & 2949 & 4556 & 33 & 1524 & 51 & 1608 & 507 & 56.9 \\
\hline 6. & NV & 4559 & 4979 & 21 & 369 & 31 & 421 & 122 & 13.6 \\
\hline 7. & $\mathrm{~L}$ & 4982 & 11068 & 94 & 5955 & 38 & 6087 & 1984 & 224.1 \\
\hline 8. & Trailer & 11069 & 11184 & & & & 116 & & \\
\hline
\end{tabular}

a Total length of a gene including 5'UTR, ORF and 3'UTR

$\mathrm{b}$ Predicted molecular weight of proteins in kilodaltons $(\mathrm{kDa})$ 


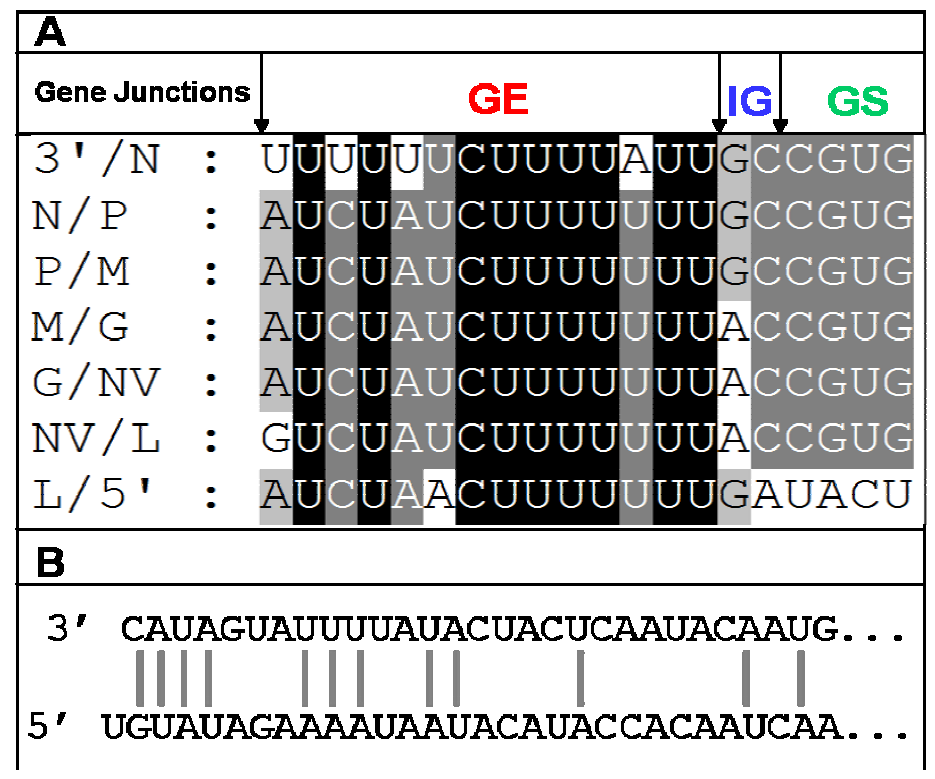

\section{Figure 2}

Analysis of the gene junctions and complementarities in the VHSV genome. A) Seven identified gene junctions of VHSV in the negative-sense of the genomic RNA are shown. 3'/N, junction of $3^{\prime}$-leader and nucleocapsid gene; N/P, junction of nucleocapsid and phosphoprotein gene; P/M, junction of phosphoprotein and matrix gene; M/G, junction of matrix and glycoprotein gene; G/NV, junction of glycoprotein and non-virion gene; NV/L, junction of non-virion and polymerase gene; L/5'-, junction of polymerase gene and 5' trailer. GE = Gene end; IG = Intergenic di-nucleotide; GS = Gene start. B)Complementarities of the 3'- and 5'-ends of the VHSV genome. The first 4 nucleotides of 3'-end are complementary to the 5 '-end nucleotides of genomic RNA, except an additional uracil $(U)$ residue at the 5 '-terminal.

Figure 4 shows the phylogenetic trees formed by comparing the deduced amino acid sequences of MI03GL strain $\mathrm{N}, \mathrm{P}, \mathrm{M}, \mathrm{NV}$ and L proteins with other VHSV strains, in which it is apparent that MI03GL proteins clusters with JF00Ehi1, KRRV9822 and Makah VHSV strains, except the $\mathrm{L}$ protein. Figure 5 shows the phylogenetic tree obtained by comparing 48 glycoprotein gene sequences of different VHSV strains, in which MI03GL clusters with subtype IVa members but forms a distinct clade, IVb.

\section{Discussion}

The Great Lakes strain of VHSV (MI03GL) was isolated from muskellunge, Esox masquinongy (Mitchill), in 2003 from Lake St. Clair, Michigan, USA. Previously, only G and $\mathrm{N}$ protein gene sequences for MI03GL strain were available and sequence analysis of the $G$ gene revealed that it is closely related to the North American genotype IVa but distinct from the three European genotypes [11]. To fully understand the molecular characteristics of the Great Lakes VHSV, we determined the complete genome sequence of MI03GL strain. The genome is 11,184 nts long and the gene organization (N, P, M, G, NV and $\mathrm{L})$ is similar to all members of the Novirhabdovirus genus. The termini of the viral genome have conserved sequences at the 3'-end (CAUAG/UU) and 5'-end (G/AAUAUG) as other members of the Novirhabdovirus genus. The first $4 \mathrm{nt}$ of the leader sequence VHSV are complementary to the last $4 \mathrm{nt}$ sequence of the trailer region (Fig 2B). The length of the 3' leader of MI03GL is 53 nts, which is similar to SHRV but slightly shorter than IHNV and hirame rhabdovirus (HIRRV; $60 \mathrm{nts}$ ). VHSV has the longest 5' trailer (116 nts) than other novirhabdoviruses, such as SHRV (42 nts), IHNV (102 nts), and HIRRV (73 nts). It is possible that the difference in length of trailer sequences may have some functional significance, which remains to be seen.

All the genes of VHSV start with a conserved gene start sequence (-CGUG-) like other novirhabdoviruses, followed by an ORF and conserved gene-end sequence (A/ GUCUAU/ACU ${ }^{7}$ ). All the genes end with 7 uracil (U) residues, which are poly adenylation signal for polymerase when it transcribes a gene. Polymerase adds poly (A) by stuttering mechanism [16]. After this poly (A) signal, there are two conserved intergenic di-nucleotides (G/AC), which are untranscribed and act as spacers between the two genes. Polymerase skips these two nucleotides to next gene-start sequence and starts transcribing the next gene 
Table 4: Percent (\%) nucleotide or deduced amino acid sequence identity of the Great Lakes VHSV-MI03GL with other VHSV strains a, b, c

\begin{tabular}{|c|c|c|c|c|c|c|c|c|c|}
\hline VHSV Strains & 3'UTR* & $\mathbf{N}$ & $\mathbf{P}$ & $M$ & $\mathbf{G}$ & NV & $\mathbf{L}$ & 5'UTR* & $\begin{array}{l}\text { Complete } \\
\text { Genome }\end{array}$ \\
\hline $07-71$ & 95 & 92 & 90 & 97 & 93 & 73 & 78 & 79 & 86 \\
\hline $\mathrm{Fil3}$ & 95 & 92 & 93 & 96 & 93 & 74 & 96 & 80 & 87 \\
\hline FA28II07* & 95 & 92 & 94 & 96 & 94 & 72 & 96 & 76 & 87 \\
\hline JF00Ehi I & 96 & 96 & 100 & 98 & 96 & 89 & 99 & 90 & 96 \\
\hline KRRV9822 & 94 & 97 & 94 & 98 & 95 & 90 & 96 & 87 & 95 \\
\hline $14-58$ & - & 93 & 93 & 96 & 94 & 74 & 96 & - & 87 \\
\hline $96-43$ & - & 93 & 94 & 98 & 93 & 75 & 97 & - & 87 \\
\hline Cod Ulcus & - & 93 & 94 & 97 & 94 & 74 & 97 & - & 87 \\
\hline Hededam & - & 93 & 94 & 97 & 94 & 76 & 97 & - & 87 \\
\hline Makah & - & 94 & 98 & 98 & 96 & 92 & - & - & - \\
\hline DK-Ip49 & - & - & - & - & - & 72 & - & - & - \\
\hline DK-Ip53 & - & - & - & - & - & 72 & - & - & - \\
\hline DK-Ip55 & - & - & - & - & - & 72 & - & - & - \\
\hline DQ159194 & - & - & - & - & - & 72 & - & - & - \\
\hline
\end{tabular}

a bold letters in rows and columns indicates VHSV strains and VHSV proteins showing highest identity with MI03GL strain b¥ only nucleotide sequences were used for analysis

c*termini sequences were incomplete; only coding sequences were available for comparison; (-) denotes that sequences are not available

[16]. Transcription of rhabdovirus mRNAs is regulated by cis-acting signals located within the 3 ' leader region and untranslated region between each gene ORF [17-20]. The Kozak context for each gene is conserved and all the genes have adenosine (A) nucleotide at -3 position before the start codon (data not shown). Among all the genes, L gene has the optimal Kozak context (-ACCATGG-) as only few copies of the L mRNA are produced inside the cell, and every single mRNA has to be utilized efficiently to make polymerase protein that is essential for both replication and transcription.

Comparison of the available VHSV sequences indicates the presence of 5 highly variable regions (HVRs) in the $\mathrm{N}$ protein: I, 38-54; II, 76-87; III, 98-131; IV, 367-375 and V, 391-393. Phylogenetic tree of the N protein shows clustering of MI03GL, JF00Ehil, KRRV9822 and Makah strains. The major variation between MI03GL and rest of above said three strains is in HVR I and IV (data not shown). The $\mathrm{N}$-terminal half of the P protein of VHSV is highly varia- ble, whereas C-terminal half is conserved. Phylogenetic tree of the P protein shows clustering of MI03GL, JF00Ehil and Makah strains. The strain isolated from Japanese flounder, JF00Ehil is $100 \%$ identical to the MI03GL. The highly conserved nature of phosphoprotein demonstrates its importance in viral replication. The matrix $(\mathrm{M})$ protein is an important structural component of virions, forming a layer between the glycoprotein containing outer membrane and the nucleocapsid core. Matrix protein of VHSV is highly conserved than any other protein. VHSV strains used in this study exhibit very close (96-98\%) identity with MI03GL. In phylogenetic analysis, JF00Ehil, KRRV9822 and Makah strains form a cluster, which is 99$100 \%$ identical to each other, and $98 \%$ identical to MI03GL. Matrix protein of rhabdovirus is involved in viral assembly, condensation of nucleocapsid, formation of bullet-shaped virion $[21,22]$ and induces apoptosis by shutdown of host cell machinery in infected cells $[23,24]$. Because it is highly essential for assembly and release of 
Table 5: Percent (\%) nucleotide or deduced amino acid sequence identity of the VHSV strain MI03GL with other rhabdoviruses

\begin{tabular}{|c|c|c|c|c|c|c|c|c|c|}
\hline Rhabdoviruses & 3'UTR* & $\mathbf{N}$ & $\mathbf{P}$ & $M$ & $\mathbf{G}$ & NV & $\mathbf{L}$ & 5'UTR* & $\begin{array}{l}\text { Complete } \\
\text { genome }\end{array}$ \\
\hline BEFV & 39 & 8 & 12 & 8 & 13 & NA & 13 & 36 & 32 \\
\hline Cereal & 27 & II & 9 & 8 & 10 & NA & 13 & 28 & 30 \\
\hline Bat & 38 & 9 & II & 10 & 18 & NA & 15 & 32 & 35 \\
\hline Maize Fine streak & 31 & 8 & 8 & 10 & 7 & NA & 13 & 32 & 30 \\
\hline Lettuce & 27 & 11 & 11 & 8 & 8 & NA & 12 & 38 & 30 \\
\hline MMV & 30 & 10 & 14 & 10 & 8 & NA & 13 & 25 & 32 \\
\hline Mokola & 41 & 10 & 8 & 12 & 19 & NA & 14 & 38 & 34 \\
\hline OFV & 27 & 8 & 7 & 2 & 7 & NA & 13 & 32 & NA \\
\hline Rabies & 38 & 10 & II & 9 & 16 & NA & 15 & 34 & 35 \\
\hline Siniperca & 34 & 8 & 7 & 8 & 13 & NA & 15 & 30 & 31 \\
\hline SVC & 35 & 9 & 8 & 5 & 17 & NA & 14 & 35 & 34 \\
\hline SYNV & 29 & 8 & 12 & 9 & 6 & NA & 13 & 22 & 30 \\
\hline Taro & 26 & 10 & 12 & 9 & 10 & NA & 14 & 33 & 32 \\
\hline Tupaia & 30 & 9 & 8 & 10 & 14 & NA & 15 & 44 & 31 \\
\hline VSV & 38 & 9 & 8 & 5 & 13 & NA & 15 & 32 & 34 \\
\hline IHNV & 35 & 40 & 35 & 36 & 38 & 16 & 60 & 35 & 56 \\
\hline HIRRV & 32 & 39 & 34 & 38 & 38 & 17 & 59 & 34 & 56 \\
\hline SHRV & 52 & 46 & 42 & 45 & 48 & 16 & 65 & 37 & 62 \\
\hline
\end{tabular}

\# Only nucleotide sequences were used for analysis

NA, not applicable

BEFV, Bovine ephemeral fever virus; Bat, European bat lyssavirus; MMV, Maize mosaic virus; Cereal, Northern cereal mosaic virus; Lettuce, Lettuce necrotic yellows virus; OFV, Orchid fleck virus; SYNV, Sonchus yellow net virus; SVC, Spring viremia of carp virus; Taro vein chlorosis virus (Taro); VSV, Vesicular stomatitis virus; IHNV, Infectious hematopoietic necrosis virus; HIRRV, Hirame rhabdovirus; SHRV, Snakehead rhabdovirus.

-Viruses belonging to Novirhabdovirus genus are in bold letters

virions, the matrix protein maintains highest homology between VHSV strains than any other protein.

The non-virion protein (NV) of VHSV shows greatest genetic diversity than any other proteins of VHSV (Table 4). It was demonstrated that NV-knockout IHNV replicates very slowly in cell culture and is non-pathogenic in fish [25]. On the contrary, NV-knockout SHRV replicates very well as wild-type virus and it was shown that NV protein of SHRV is not essential for pathogenesis [26]. These studies suggested that each species of Novirhabdovirus genus has its own characteristics and one can not ignore the importance NV in pathogenesis. The wide host-range for VHSV suggests that the tropism and the pathogenicity not only reside in glycoprotein gene, but also in other genes, especially the NV gene. The L protein displays the highest level of sequence homology among members of various genera of Rhabdoviridae family (Table 5). All the available L sequences for VHSV strains show highest conservation $(98 \%)$ as that of the matrix protein. 


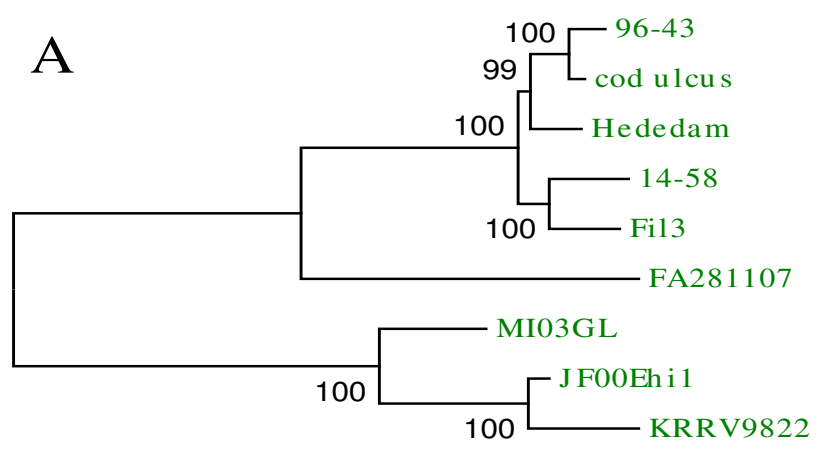

$$
\stackrel{1}{0.01}
$$

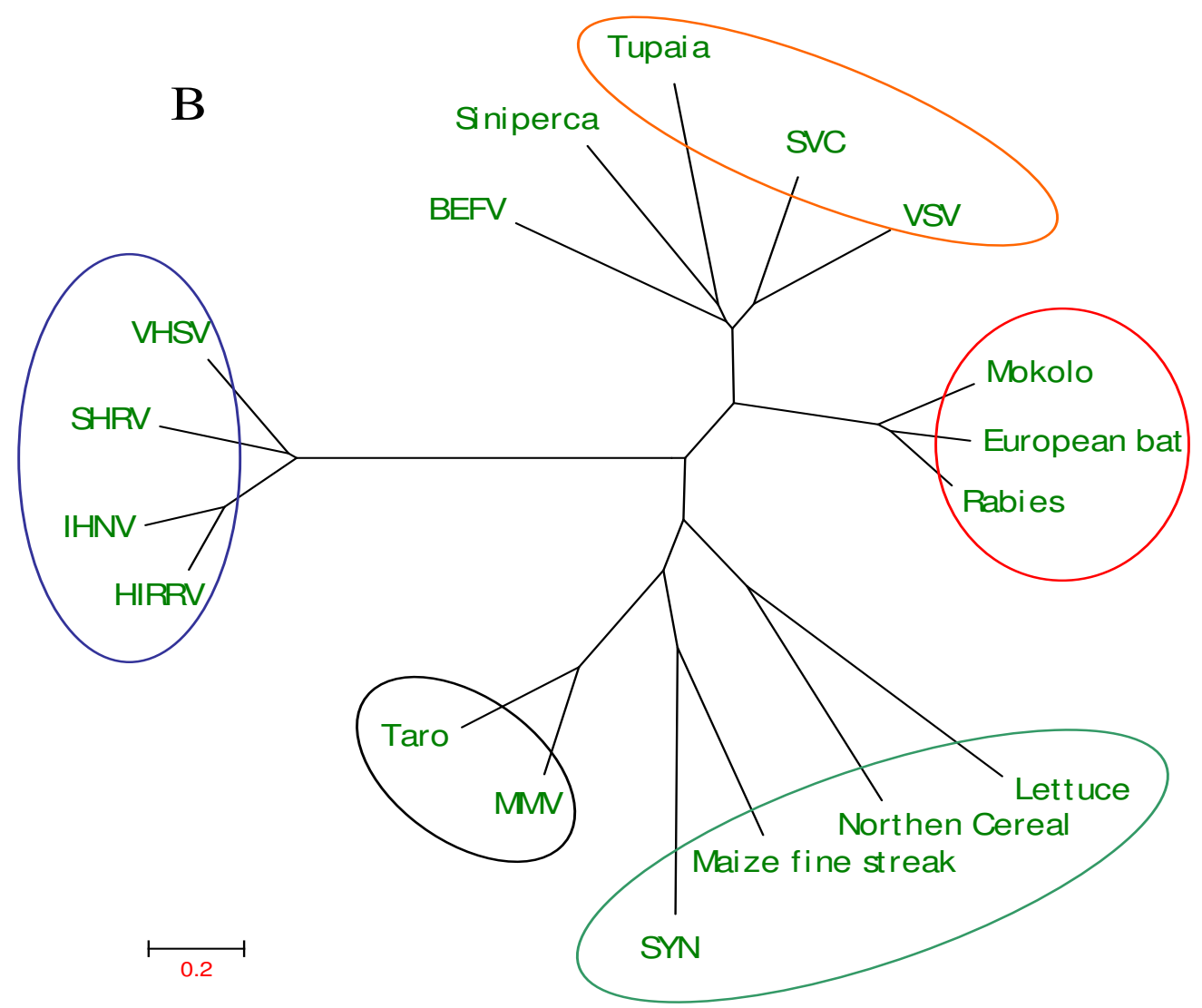

Figure 3

Phylogenetic tree analysis of the deduced amino acid sequences of VHSV (A) and various other rhabdovirus genomes (B). Information about the VHSV strains and rhabdoviruses sequences used in this analysis is described in Table 2. Rhabdoviruses belonging to the same genus are circled in B. Novirhabdovirus (Blue); Lyssavirus (Red); Vesiculovirus (Orange); Cytorhabdovirus (Teal); Nucleorhabdovirus (Black); BEFV-Ephemerovirus; Siniperca-unclassified rhabdovirus. Phylogenetic tree analysis was conducted by neighbor-joining method using 1000 bootstrap replications. The scale at the bottom indicates the number of substitution events and bootstrap confidence values are shown at branch nodes. 


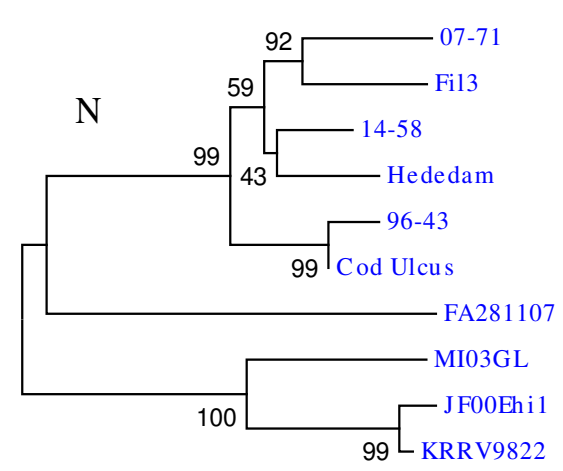

$\underset{0.005}{\longmapsto}$

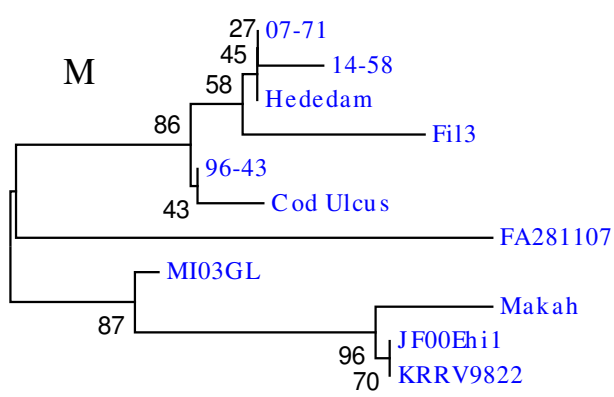

$\underset{0.005}{\longmapsto}$

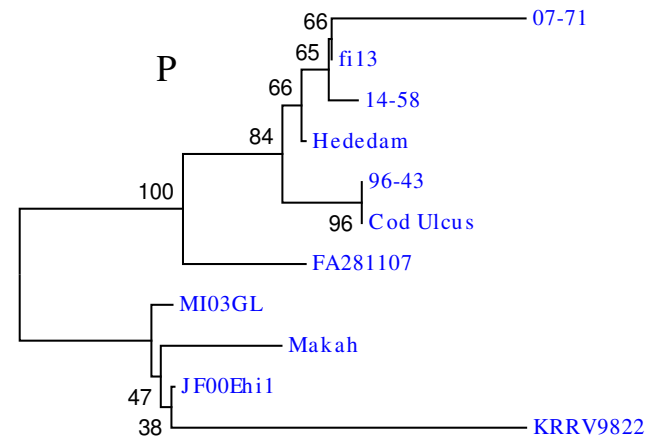

$\stackrel{\vdash}{0.01}$
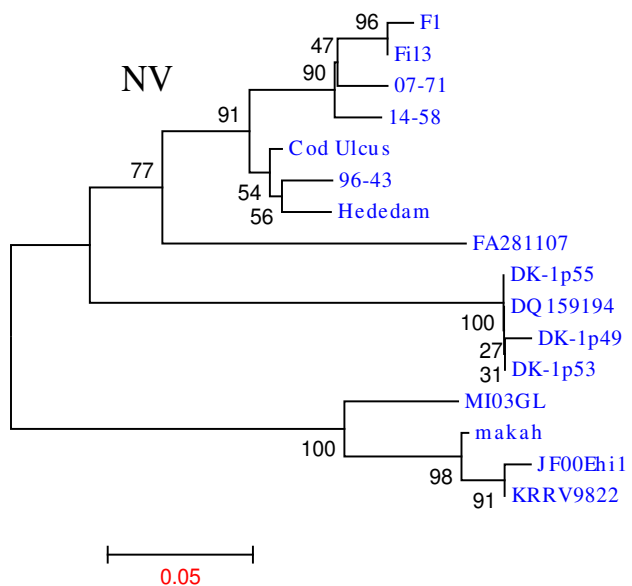

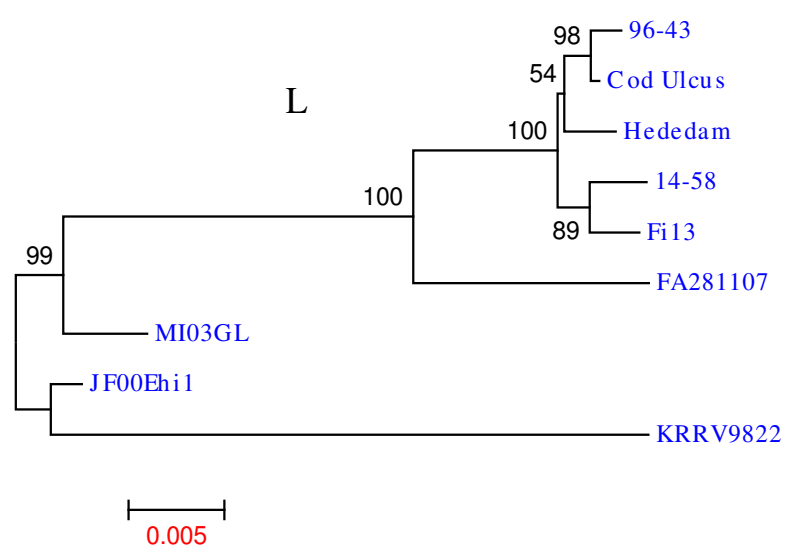

\section{Figure 4}

Phylogenetic tree analysis of the deduced amino acid sequences of nucleocapsid (N), matrix (M), phosphoprotein (P), non-virion protein (NV) and polymerase protein (L) of various VHSV strains. Information about the VHSV strains used in this analysis is described in Table 2. Phylogenetic tree analysis was conducted by neighbor-joining method using 1000 bootstrap replications. The scale at the bottom indicates the number of substitution events and bootstrap confidence values are shown at branch nodes. 


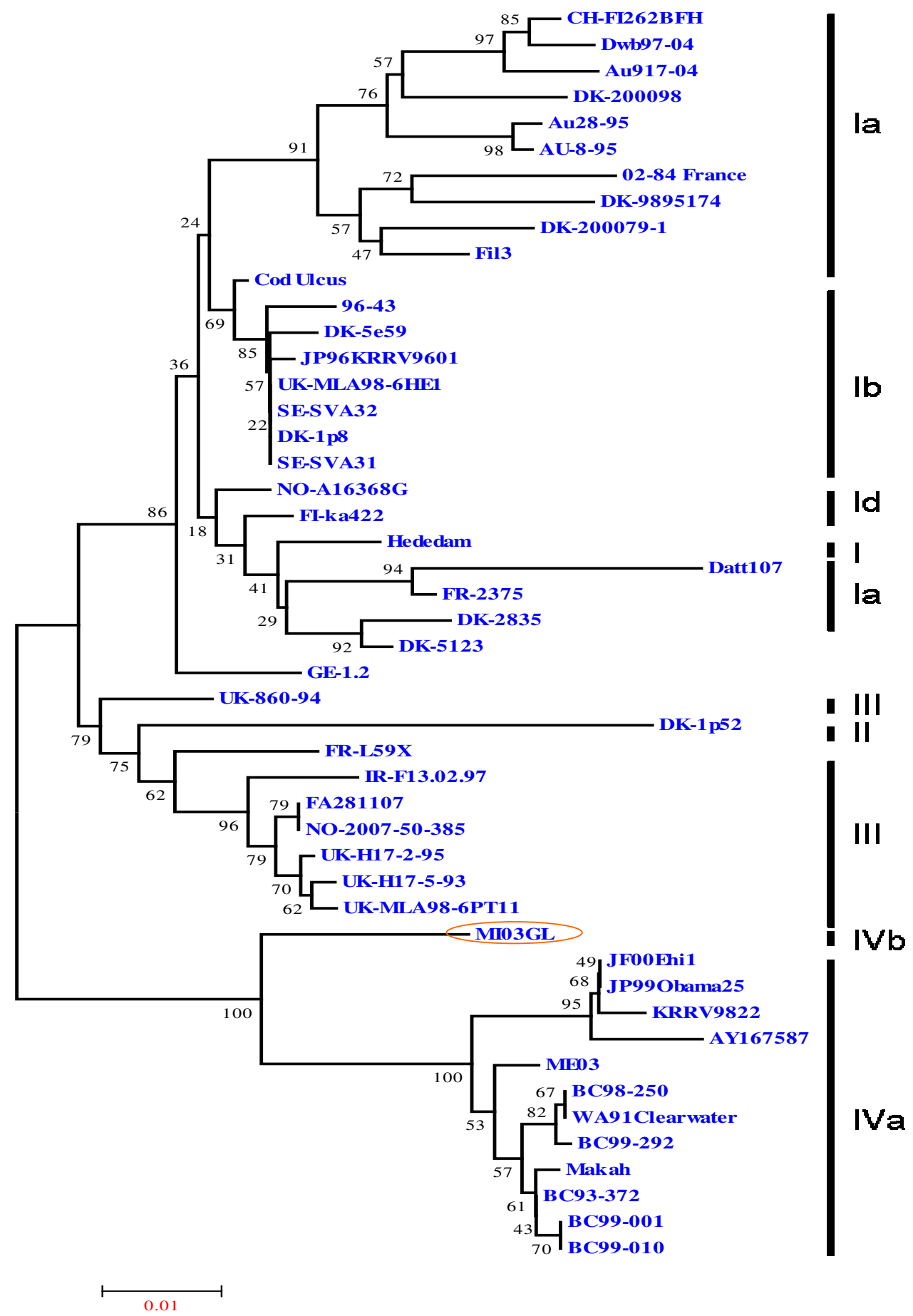

Figure 5

Phylogenetic relationship of the full-length glycoprotein (G) sequences of $\mathbf{4 8}$ VHSV strains. Genotypes and sublineages are depicted by bold vertical lines, as described by Einer-Jensen et al. (2004) and Elsyad et al., 2006. The Great Lakes strain MI03GL (circled) forms different sublineage IVb, whereas rest of the North American VHSV isolates falls under sublineage IVa. Data of virus isolates used here are shown in Table 2. Phylogenetic tree analysis was conducted by neighbor-joining method using 1000 bootstrap replications. The scale at the bottom indicates the number of substitution events and bootstrap confidence values are shown at branch nodes. 
Genomic comparison of VHSV strains isolated from various marine species from different parts of the world sheds light on the correlation of genetic sequences with viral tropism and pathogenicity. The glycoprotein is believed to be involved in virulence and tropism because of it's involvement in viral attachment and cell entry [27]. Comparison of the glycoproteins of various VHSV strains has revealed only few blocks of conserved region (data not shown). The regions between residues 53-70; 140-156; 232-253 and 389-413, are highly conserved and the rest of the region shows genetic variations which are scattered all over the protein. The major neutralizing epitopes have been mapped to two antigenic sites for IHNV, at amino acids 230-231 and 272-276 [28,29]. In this analysis, we found no amino acid substitutions at positions 230-231 among 48 strains compared, except two. On the other hand, residues 270-281 are highly variable, which supports earlier findings and suggests the involvement of this site in antigenic variation and virulence [30].

In phylogenetic analysis of the G proteins, MI03GL forms a separate branch in genotype IVa (Fig. 5) and is sub-typed as IVb, as demonstrated earlier [11]. Although JF00Ehil, KRRV9822 and Makah strains maintain close identity with MI03GL, they are sub-typed as IVa. The genogroups of VHSV are determined based on the restriction fragment length polymorphism patterns of the G protein [31]. Makah maintains a close identity with Japanese JF00Ehil (99\%) and KRRV9822 (98\%), and North American isolates $(99 \%)$. Phylogenetic tree of the G protein explicitly demonstrates the relationship of Makah strain with members of genotype IV. Makah strain isolated from Coho Salmon in 1988 from Washington, USA was grouped under genotype IVa [31]. Rests of the North American strains belonging to genotype IVa were isolated in different time periods (1991-2003) [11], and Japanese strains were isolated around year 2000. Isolates of genotype IV have been recovered mainly in North America, Japan and Korea [31,32] but not in Europe where genotypes I, II and III are prevalent. It was suggested that VHSV strains circulating in a defined geographical area have a remarkably conserved G gene, regardless of the elapsed time or the different host species [33]. These earlier reports and the current study suggests that the genotype IV strains of VHSV probably originated from North America and possible ancestor for isolates of genotype IV might be Makah. This suggests that MI03GL might have diverged from Makah and evolved independently thereafter. To date, among VHSV strains, MI03GL strain is the only member of the genotype IVb.

\section{Competing interests}

The authors declare that they have no competing interests.

\section{Authors' contributions}

VNV conceived the study. AA planned the experimental design and carried out cloning and sequencing. AA drafted the manuscript. All authors critically reviewed and approved the final manuscript.

\section{Acknowledgements}

We thank Dr. Gael Kurath for kindly providing the VHSV-MI03GL genomic RNA and William N Batts for technical assistance.

\section{References}

I. Schlotfeldt HI, Ahne W: Epizootics in brown trout (Salmo trutta fario) caused by VHSV-FI. J App Ichthyol I 988, 4: I47-I 148.

2. Hopper K: The isolation of VHSV from salmon at Glenwood Springs, Orcas Island, Washington. Am Fish Soc Fish Health News 1989, 17:1

3. Schlotfeldt HJ, Ahne W, Vestergard-Jorgensen PE, Glende W: Occurrence of viral haemorrhagic septicaemia in turbot (Scophthalmus maximus)-a natural outbreak. EAFP Bull I991, I I:I05-7.

4. Meyers TR, Sullivan J, Emmeneger E, Follet J, Short S, Batts WN: Identification of viral haemorrhagic septicemia virus isolated from pacific cod, Gadus macocephalus in prince William Sound, Alaska, USA. Dis Aquat Org 1992, I 2:167-75.

5. Brudeseth $B E$, Evensen $O$ : Occurrence of viral haemorrhagic septicemia virus (VHSV) in wild marine fish species in the coastal regions of Norway. Dis Aquat Org 2002, 52:2I-28.

6. Tordo N, Benmansour A, Calisher C, Dietzgen RG, Fang RX, jackson AO, Kurath G, Nadin-Davis S, Tesh RB, Walker P: Family Rhabdoviridae. In The eighth report of the international committee for taxonomy of viruses Academic Press, San Diego; 2004.

7. Kurath G, Leong JA: Characterization of infectious hematopoietic virus mRNA species reveals a nonvirion rhabdovirus protein. J Virol 1985, 53:462-468.

8. Schütze H, Enzmann PJ, Mundt E, Mettenleiter TC: Identification of the non-virion (NV) protein of fish rhabdoviruses viral haemorrhagic septicaemia virus and infectious haematopoietic necrosis virus. J Gen Virol 1996, 77:1259-1263.

9. Schütze $H$, Mundt E, Mettenleiter TC: Complete genomic sequence of viral haemorrhagic septicemia virus, a fish rhabdovirus. Virus Genes 1999, 19:59-65.

10. Betts AM, Stone DM: Nucleotide sequence analysis of the entire coding regions of virulent and avirulent strains of viral haemorrhagic septicemia virus. Virus Genes 2000, 20:259-262.

II. Elsayed E, Faisal M, Thomas M, Whelan G, Batts W, Winton J: Isolation of viral haemorrhagic septicemia virus from muskellunge, Esox masquinongy (Mitchill), in Lake St. Clair, Michigan, USA reveals a new sublineage of the North American genotype. J Fish Dis 2006, 29:6 I I-6I9.

12. Haas RC: The muskellunge of Lake St. Clair. Volume II. American Fisheries Society Special Publication; 1978:334-339.

13. Nicholas KB, Nicholas HBJ, Deerfield DW: GeneDoc: analysis and visualization of genetic variation. EMBNEW NEWS 1997, 4:14.

14. Tamura K, Dudley J, Nei M, Kumar S: Molecular evolutionary genetics analysis (MEGA) software version 4.0. Mol Biol Evol 2007, 24:1596-I599.

15. Schnell MJ, Buonocore L, Whitt MA, Rose JK: The minimal conserved transcription stop-start signal promotes stable expression of a foreign gene in vesicular stomatitis virus. J Virol 1996, 70:2318-2323.

16. Banjerjee AK: Transcription and replication of rhabdoviruses. Microbiol Rev 1987, 5 I :66-87.

17. Wertz GW, Whelan S, LeGrone A, Ball LA: Extent of terminal complementarity modulates the balance between transcription and replication of vesicular stomatitis virus RNA. Proc Natl Acad Sci 1994, 9 1:8587-8591.

18. Barr JN, Whelan SP, Wertz GW: cis-Acting signals involved in termination of vesicular stomatitis virus mRNA synthesis include the conserved AUAC and the U7 signal for polyadenylation. J Virol 1997, 71:8718-8725.

19. Barr JN, Wertz GW: Polymerase slippage at vesicular stomatitis virus gene junctions to generate poly $(A)$ is regulated by the upstream 3'-AUAC-5' tetranucleotide: implications for 
the mechanism of transcription termination. I Virol 200I, 75:690I-69I3.

20. Whelan SP, Wertz GW: Regulation of RNA synthesis by the genomic termini of vesicular stomatitis virus: identification of distinct sequences essential for transcription but not replication. J Virol 1999, 73:297-306.

21. Newcomb WW, Brown JC: Role of the vesicular stomatitis virus matrix protein in maintaining the viral nucleocapsid in the condensed form found in native virions. J Virol 198I, 39:295-299.

22. Mebatsion T, Weiland F, Conzelmann KK: Matrix protein of rabies virus is responsible for the assembly and budding of bulletshaped particles and interacts with the transmembrane spike glycoprotein G. J Virol 1999, 73:242-250.

23. Finke $S$, Conzelmann KK: Replication strategies of rabies virus. Virus Res 2005, I I I: |20-131.

24. Kassis R, Larrous F, Estaquier J, Bourhy H: Lyssavirus matrix protein induces apoptosis by a TRAIL-dependent mechanism involving caspase-8 activation. J Virol 2004, 78:6543-6555.

25. Thoulouze MI, Bouguyon E, Carpentier C, Bremont M: Essential role of the NV protein of Novirhabdovirus for pathogenicity in rainbow trout. J Virol 2004, 78:4098-4I07.

26. Alonso $\mathrm{M}, \mathrm{Kim} \mathrm{CH}$, Johnson MC, Pressley M, Leong JA: The NV gene of snakehead rhabdovirus (SHRV) is not required for pathogenesis, and a heterologous glycoprotein can be incorporated into the SHRV envelope. J Virol 2004, 78:5875-5882

27. Bearzotti M, Monnier AF, Vende P, Grosclaude J, de Kinkelin P, Benmansour $A$ : The glycoprotein of viral hemorrhagic septicemia virus (VHSV): antigenicity and role in virulence. Vet Res 1995, 26:413-422.

28. Huang C: Mapping of antigenic sites of infectious hematopoietic necrosis virus glycoprotein. In $\mathrm{PhD}$ thesis University of Washington, Seattle, USA; 1993.

29. Kim $\mathrm{CH}$, Winton JR, Leong JC: Neutralization-resistant variants of infectious hematopoietic necrosis virus have altered virulence and tissue tropism. J Virol 1994, 68:8447-8453.

30. Benmansour A, Basurco B, Monnier AF, Vende P, Winton IR, de Kinkelin $P$ : Sequence variation of the glycoprotein gene identifies three distinct lineages within field isolates of viral haemorrhagic septicaemia virus, a fish rhabdovirus. J Gen Virol 1997, 78:2837-2846.

31. Einer-Jensen K, Winton J, Lorenzen N: Genotyping of the fish rhabdovirus, viral haemorrhagic septicaemia virus, by restriction fragment length polymorphisms. Vet Microbiol 2005, 106:167-178.

32. Snow M, Cunningham CO, Melvin WT, Kurath G: Analysis of the nucleoprotein gene identifies distinct lineages of viral haemorrhagic septicaemia virus within the European marine environment. Virus Res 1999, 63:35-44.

33. Stone DM, Way K, Dixon PF: Nucleotide sequence of the glycoprotein gene of viral haemorrhagic septicaemia (VHS) viruses from different geographical areas: a link between VHS in farmed fish species and viruses isolated from North Sea cod (Gadus morhua L.). J Gen Virol 1997, 78: |3| 9-1326. 